\title{
Coastal Lagoons and Estuaries in Mexico: Processes and Vulnerability
}

\author{
Victor F. Camacho-Ibar • Victor H. Rivera-Monroy
}

Received: 20 August 2014 / Revised: 21 September 2014 / Accepted: 22 September 2014 / Published online: 3 October 2014

(C) Coastal and Estuarine Research Federation 2014

Coastal lagoons and estuaries provide critical ecosystem goods and services to society and the majority of the world's population live in coastal regions (Bianchi et al. 1999; Bianchi 2007; McGranahan et al. 2007; Michael and Paerl 2010). However, population growth, land and water use alteration, and habitat fragmentation in connecting coastal watersheds reduce the productivity and health of the coastal environment (Day et al. 2007; Borja et al. 2008). A detailed analysis of coastal systems, ecological dynamics, and carrying capacity is needed to avoid further ecological damage that would endanger human economic and functional dependence on these valuable ecosystems (Borja and Dauer 2008). Understanding the ecogeomorphology and biogeochemistry of coastal regions requires the consideration of humans as agents of change (Borja et al. 2008; Hopkinson et al. 2008; Bauer et al. 2013).

The Mexican coastal zone encompasses complex geomorphological settings along a 11,600 km coastline (RiveraArriaga and Villalobos 2001) that interacts with a wide continental shelf $\left(500,000 \mathrm{~km}^{2}\right)$, particularly in the Gulf of Mexico (Rivera-Arriaga and Villalobos 2001; Yañez-Arancibia and Day 2004b; Yañez-Arancibia et al. 2013) and the Gulf of California (Lluch-Cota et al. 2007). Landforms along both the Pacific and Gulf of Mexico coasts are widely diverse due to their geological history and include reef coasts, sedimentary

Communicated by Iris C. Anderson and Wayne S. Gardner

V. F. Camacho-Ibar

Instituto de Investigaciones Oceanológicas, Universidad Autónoma de Baja California, Apdo. Postal 453, Ensenada, Baja California CP 22860, Mexico

\section{H. Rivera-Monroy $(\varangle)$}

Department of Oceanography and Coastal Sciences, School of the Coast and Environment, Louisiana State University, 3209 Energy, Coast, and Environment Building, Baton Rouge, LA 70803, USA e-mail: vhrivera@1su.edu basins, karstic environments, and volcanic/tectonic rocky coasts (Seingier et al. 2011). Despite Mexico's extensive area of estuaries $\left(16,000 \mathrm{~km}^{2}\right)$ and coastal lagoons $\left(12,500 \mathrm{~km}^{2}\right)$ (Ortiz-Lozano et al. 2005), there is limited information about the hydrology and hydrodynamic patterns of these systems, including changes associated with human activities (Rivera-Arriaga and Villalobos 2001). Major human activities altering coastal hydrological patterns in Mexico include road construction, urban development, coastal tourism, and oil and gas exploration (Ruiz-Luna and BerlangaRobles 2003; Murray 2007; Vidal and Filograsso 2008). These alterations may lead to increased water residence times that exacerbate eutrophic conditions in coastal waters already affected by agricultural activities (i.e., fertilizers) and untreated sewage loads (e.g., Paez-Osuna et al. 1998; Ahrens et al. 2008).

The sustainability of economic development in Mexican coastal regions is strongly affected by extensive watersheds, particularly in the Gulf of Mexico (Lozano et al. 2000; Sanchez-Gil et al. 2004; Cruz and McLaughlin 2008; YanezArancibia et al. 2013), where discharge from the four largest rivers in the country (Grijalva-Usumacinta, Papaloapan, Coatzacoalcos, and Pánuco; total discharge 208,621× $10^{6} \mathrm{~m}^{3}$ year $^{-1}$ ) (NWCM-CONAGUA 2008) delivers sediment and nutrients that control coastal productivity (e.g., fisheries and aquaculture) (Espinoza-Tenorio et al. 2011) and supports hydroelectric power generation (NWCMCONAGUA 2008). Riverine discharge subjects estuarine and coastal areas to nutrient enrichment and hydrocarbon and pesticide pollution from surface water runoff, atmospheric deposition, and groundwater discharges (Delgado-Gonzalez et al. 2011). The Mexican coastline plays a critical role in the country's economy. However, it is not clear what the net response of these coastal ecosystems will be to multiple stressors, from human caused perturbations (e.g., land use, nutrient enrichment, and pollution) (Sanchez-Gil et al. 2004; 
Ortiz-Lozano et al. 2005) to short-term episodic events such as hurricanes and long-term climate change. (Ortiz-Lozano et al. 2005; Adger et al. 2005b; Adger 2006; Rivera-Arriaga and Villalobos-Zapata 2005; Lluch-Cota et al. 2007; Vidal and Filograsso 2008; Espinoza-Tenorio et al. 2011; CalderonAguilera et al. 2012; Jauregui 2003).

River discharge is a major driver of ecological and biogeochemical processes in estuarine systems in temperate latitudes (Bianchi 2007), yet coastal lagoons and estuaries in Mexico occur in a variety of climates, ranging from arid to humid tropical (Yañez-Arancibia et al. 2013) that significantly affect hydrology and water storage (Contreras-Espinosa and Warner 2004; Carrillo-Rivera et al. 2008; Gonzalez-Zamorano et al. 2013). Indeed, drivers such as intense solar radiation, evaporation, inverse and reversing density gradients, torrential rain, coastal upwelling, and groundwater discharges favor a range of interacting physical and biogeochemical processes in coastal Mexican ecosystems that are not typically present in temperate estuaries (Ortiz-Lozano et al. 2005; Rivera-Monroy et al. 2011).

Papers included in this special feature address biogeochemical and physical responses to a range of climate conditions allowing the evaluation of the vulnerability of coastal ecosystems in Mexico to both natural and increasing human impacts. This special feature results from the presentations in the session "Coastal Lagoons and Estuaries in Mexico: Processes and Vulnerability" at the 21st Biennial Conference of CERF held at Daytona Beach, Florida on November 7, 2011.

Despite the multiple efforts to synthesize information about ecosystem health in Mexican coastal ecosystems, progress is limited by the lack of data on a number of coastal processes including nutrient cycling and primary productivity, hydrodynamic patterns, and large-scale climate disturbances such as tropical cyclones (Ortiz-Lozano et al. 2005). In this section, we include six articles that address these environmental processes across a wide range of spatial and temporal scales. Two papers determine water circulation patterns and water residence times in coastal regions with contrasting hydrological conditions and geomorphological settings, represented by the Baja California and Yucatan peninsulas. Indeed, one study evaluates the current velocity profiles of Bahia Concepcion, a semiarid bay (average depth: $20 \mathrm{~m}$ ) located along the western coastline of the Baja California Peninsula, which exchanges water with the highly productive Gulf of California (Lluch-Cota et al. 2007). Only a few studies have evaluated specific mechanisms responsible for observed wind-driven circulation patterns, which were modified by variable bathymetry in semi-enclosed basins in subtropical and tropical regions in coastal Mexican systems (Winant et al., 2014). The maximum water column stratifications measured in a cross section of Bahia Concepcion ranged from 3 to $4{ }^{\circ} \mathrm{C} \mathrm{m}^{-1}$ throughout the study period and were influenced by winddriven flows. Low-pass filtered flows showed more complicated structures than those predicted from theory. Furthermore, a cyclonic recirculation observed during unstratified conditions persisted below the thermocline during the stratified season. This recirculation is apparently caused by a relatively flat bathymetry and is influenced by advective accelerations. One major conclusion from this work is that although the dominant complex empirical orthogonal velocity was vertically sheared for most of the cross section, it explained only $\sim 33 \%$ of the observed variability; in fact, all circulation modes displayed a rich spatial structure with vertical and lateral variations. These results underscore new challenges to the modeling of wind-driven stratified flows in semi-enclosed basins.

Similar to the work by Winant et al. (2014), Medina et al. (2014) evaluated how wind and tidal forcing, which influence hydrodynamics, control the water balance and landscape water level pattern in Bahia de la Ascencion (BA), located in the Yucatan Peninsula. Certainly, the Yucatan (Gulf of Mexico coast) and the Baja California (Pacific coast) peninsulas differ geologically; the Pacific coast is composed of metamorphic rocks (Paleozoic) partially as a result of the subduction of the Cocos Plate beneath the North American Plate resulting in terrain elevations of up to $2000 \mathrm{~m}$ (e.g., Sierra Madre del Sur) along the Pacific coast (south of $21^{\circ} \mathrm{N}$ ) (Farfan et al. 2014). In contrast, the Yucatan Peninsula is characterized by limestone, clastic, and coastal alluvial rocks of different geological ages. Thus, Bahia de la Ascencion is a flooded karst depression with a maximum depth of $6.8 \mathrm{~m}$. In this coastal body, $16 \%$ of the rain falling over the entire BA drainage basin became groundwater discharge and surface runoff during the dry season; in contrast, during the rainy season, $68 \%$ of the precipitation input to the drainage basin was supplied through groundwater-surface runoff to the bay (Medina et al. 2014). This contrasting seasonal freshwater supply into the BA was reflected in the mesohaline conditions in the southwest bay while saline water masses (a horizontal SW-NE estuarine salinity gradient) in the inlet were influenced by prevalent SE winds and tidal phase.

In addition to limited information on hydrography and hydrodynamics in Bahia de la Ascencion, information is lacking on water quality spatial patterns (Medina et al. 2014). This information gap is relevant from the management point of view, given the increasing development of the tourism industry in Mexican Caribbean coastal areas, where the compounded effects of fresh water demand/consumption and inadequate management of wastewater represent a current threat to the ecological properties of these oligotrophic coastal systems. This threat to the sustainability of coastal ecosystems resulting from increasing eutrophication is not unique to the Mexican Caribbean. As one example, eutrophication is also a major problem in the Pacific Northwestern region. Nitrogen dynamics operate differently in the subtropical Tóbari estuary than in many temperate estuaries, where nitrification- 
denitrification is a "sink" for nitrogen and helps ameliorate the impacts of excess nitrogen inputs into coastal zones (Beman 2014). The Tóbari estuary, located in the Yaqui Valley, is influenced by intensive agriculture, with a total $\mathrm{N}$ flux estimated at $10^{6} \mathrm{~kg} \mathrm{~N}$ year $^{-1}$. Nitrification and denitrification potentials and the abundances of archaeal ammonia monooxygenase (amoA) and bacterial nitrite reductase (nirS) genes were compared in sediments across five sites (sediments) in the estuary. Bacterial nirS genes outnumbered archaeal amoA genes significantly (3- to 49-fold) and were more abundant in the northern part of the estuary. Although amoA abundance was related inversely to ambient temperature, neither amoA nor nirS were correlated with nitrification or denitrification potentials. Nitrification appears to be limited within subtropical estuarine sediments, especially under heavy loads of inorganic nitrogen into the coastal zone. Unfortunately, comparative $\mathrm{N}$ cycling studies among Mexican coastal ecosystems are lacking; thus, studies similar to the one of Beman are needed to evaluate how excess inorganic nutrients are metabolized in coastal regions. Such results are needed for the development of appropriate management plans.

Another study assessing eutrophication conditions in tropical coastal waters involved using an in situ microcosm approach (e.g., Varona-Cordero et al. 2014) to determine the response of phytoplankton to a range of inorganic nitrogen $(\mathrm{N})$, phophorus (P), and silica (Si) additions to the highly eutrophic La Mancha lagoon in the Gulf of Mexico; inorganic phosphorus concentrations at this site can reach $9 \mu \mathrm{M} . \mathrm{N}, \mathrm{P}$, and $\mathrm{Si}$ were added in various combinations to enclosed water columns during the dry season and the phytoplankton community response was followed. Phytoplankton composition shifted from a community initially dominated by dinoflagellates (e.g., Prorocentrum spp.) to one dominated by diatoms (Thalassiosira spp. and Nitzschia longissima) when the concentration of water column DIN increased twofold over that initially observed, following a nutrient amendment (ratio of $\mathrm{N}: \mathrm{P}$ of 16). Despite the chronic eutrophic conditions in $\mathrm{La}$ Mancha lagoon, this study reveals that the lagoon is N-limited during the dry season and provides evidence of successional patterns and mechanisms regulating phytoplankton growth rates and diversity. These results show that diatoms in $\mathrm{La}$ Mancha lagoon are highly competitive due to fast nutrient assimilation rates; thus, these species are positioned towards the end of the "Mandala" succession model (Margalef et al. 1979) and could be considered as velocity specialists (Sommer 1985). Despite the utility of nutrient-enrichment experiments, most previous studies of nutrient enrichment on phytoplankton growth and community structure were performed in temperate latitudes and rarely in tropical regions, particularly in the neotropics (Varona-Cordero et al. 2014).

In contrast to the eutrophic environmental conditions in La Mancha lagoon, a hydrogeochemical study in an oligotrophic coastal lagoon located in the northwestern Yucatan Peninsula partitioned sources of water to the system (Stalker et al. 2014). This region is highly karstic in nature with extensive secondary porosity produced by dissolution from both acidic precipitation infiltration and from the movement and chemistry of the saltwater-freshwater mixing zone. The Yucatan Peninsula is distinguished by a lack of surface water systems (i.e., rivers) but groundwater discharge to the coastline and estuaries is conspicuous (Carrillo-Rivera et al. 2008; Perry et al. 2009). Few published studies quantify the contribution of these groundwater inputs to the Yucatan coastal region (Stalker et al. 2014). Salinity and geochemical tracers $\left(\delta^{18} \mathrm{O}\right.$ - and strontium) helped discern the sources of water to Celestún lagoon. Two dominant sources of water were identified: brackish groundwater in the northern lagoon and seawater from the south western Gulf of Mexico, which together represent $80 \%$ of the water inputs. A clear spatial distribution in the isotopic signatures was observed. A third source, the fresh "local" groundwater end-member, was the least dominant of the three major sources, but was present in all samples; its geochemical composition suggested short flow paths. The $\delta^{18} \mathrm{O}$ spatial distribution indicated freshwater discharge along the entire eastern boundary of the lagoon where mangrove wetlands are the dominant vegetation sites. The increased human development both inland and at the town of Celestun has resulted in increased extraction of freshwater resources and may change the water budgets in Celestún lagoon.

Further sampling is necessary in the Celestún lagoon to capture the potential differences in isotopic signatures reflecting the contribution of precipitation to the total water budget because the two samplings occurred under dry conditions (Stalker et al. 2014). Despite the uncertainty in identifying seasonal differences in water sources, the authors show that their geochemical approach to construct water budgets in karstic environments is robust, and its application to other coastal estuarine systems in the region would allow the development of an overall hydrologic budget for the Yucatan Peninsula. They suggest that the simultaneous mixing equations used in their calculations may be useful with other tracers and inputs for coastal systems with different lithologies and water sources.

Understanding the role of pulsing climatic events such as tropical storms and hurricanes in altering seasonal precipitation patterns and therefore overall water budgets in the Yucatan Peninsula coastal region is needed (Stalker e al. 2014). The impact of large scale disturbances on the spatial distribution of precipitation and coastal chlorophyll a concentrations (as a proxy for primary productivity) is analyzed in this issue, particularly in the case of the Baja California and Yucatán Peninsulas, which encapsulate extensive areas of the Mexican coastline (Farfan et al. 2014). Patterns of landfall activity of tropical cyclones (TCs) were assessed from 1970 to 2010, and high landfall frequency was identified along the 
Mexican east and west coasts (Farfan et al. 2014). Linkages between TC strength and the intensity of precipitation and chlorophyll a spatial variability after TC passage were also evaluated. The authors identified 1065 named TCs with a wide diversity of tracks; the highest number of landfalls were registered in the states of Baja California Sur and Sinaloa on the west coast and Quintana Roo on the east coast. This spatial pattern of TC landfalls on the Mexican coastline from both the Atlantic and the eastern Pacific basins is unique in tropical and subtropical latitudes since the eastern Pacific TCs solely impact the western coast whereas the Atlantic TCs only impact the eastern coast of Mexico. Based on the 20 highest precipitation events at TC landfalls on the east and west coasts of Mexico, TC contributions to annual rainfall were higher along the west coast (64-172\%) than on the east coast (31-71\%) (Farfan et al. 2014). Furthermore, six of the 20 -year accumulation events analyzed in the study contributed more than $100 \%$ of the long-term mean annual precipitation during passage through Baja California Sur. The increases in chlorophyll $a$ values following TC landfalls in the Baja California and Yucatán Peninsulas were linked to TC strength, intensity of precipitation, spatial scales of the two peninsulas, and the relative movement of the TCs. Although the relationship between river discharge and nutrient loading was not measured directly, their study underscores the significant role of TCs in controlling not only coastal primary productivity (chlorophyll $a$ ) during short periods of time after hurricane impact.

The long-term analysis of frequencies, trajectories, and landings of TCs that impact Mexico's Gulf of Mexico, Caribbean Sea, and Pacific Ocean coastlines highlights the strong impact of natural large-scale disturbances on the climate, weather, hydrology, and coastal aquatic primary productivity, among other geophysical and ecological processes (Farfan et al. 2014). This observation underscores the need to continue assessing the degree of vulnerability of Mexican coastal ecosystems as natural and human disturbances interact at different spatial scales under climate change.

The definition of vulnerability as "the degree of which a system, subsystem, or system component is likely to experience harm due to exposure to a hazard, either a perturbation or stress/stressor" (Turner et al. 2003a) has evolved into complex conceptual frameworks during the last 10 years, as it is recognized that the best approach to understand, ameliorate, and manage ecosystems is by the use of an integrated socioecosystem approach (Turner et al. 2003b; Adger et al. 2005a, b; Gallopin 2006; Nelson et al. 2007; Turner 2010; Collins et al. 2011). The identification of the conceptual relationships among vulnerability, resilience, and adaptive capacity in the management of Mexican coastal ecosystems is currently lacking (Bezaury-Creel 2005; Seingier et al. 2011), particularly in the context of global climate change including increases in temperature and sea level (McGranahan et al. 2007). This gap in the availability of data, information, and models is not surprising given the absence of comparative regional studies (Rivera-Monroy et al. 2008; Vidal and Filograsso 2008), for example, on the influence of TCs in controlling water resource availability and their effect on nutrient and carbon cycling in the coastal zone (Ahrens et al. 2008; Seingier et al. 2011) or the economic impact of eutrophication on the sustainability of ecosystems services provided by coastal wetlands (e.g., Contreras-Espinosa and Warner 2004; Camacho-Valdez et al. 2013) such as commercial fisheries (Yanez-Arancibia and Day 2004a; Aburto-Oropeza et al. 2008; Martínez Arroyo et al. 2011; Aguilar Ibarra et al. 2013). We foresee the contribution of the six papers included in this special section as a step in both closing the knowledge gap and the development of an integrated research agenda for the implementation of long-term socio-ecological studies (Burgos et al. 2007; Jardel et al. 2013) in estuaries and tropical lagoons, not only in Mexico, but also in other tropical latitudes.

Acknowledgments VFCI participation in the preparation of the special section was provided by the Universidad Autónoma de Baja California Academic Mobility Program 2011. Partial funding for VHRM participation was provided by the Consejo Nacional de Ciencia y Tecnologia (CONACyT) to the Red Mex-LTER program (CONACyT-Fondo Institucional: I0002; Proyecto\# 24847, Etapa: 001) through the project "Demandas Hidrológicas de los Ecosistemas Naturales en Mexico: Fase 1", the Florida Coastal Everglades Long Term Ecological Research (FCELTER) program funded by the USA-National Science Foundation (Grants \#DBI-0620409 and \#DEB-9910514) as part of its international collaboration initiative, and the NASA-JPL project (LSU Subcontract\# 1452878) "Vulnerability Assessment of Mangrove Forest Regions of the Americas". We want to thank the individual reviewers that helped bring this section to fruition for their time and dedication. We are also extremely grateful to Iris C. Anderson (Reviews Editor) and Wayne S. Gardner (CoEditor in Chief) for their guidance and support during the preparation of this special section.

\section{References}

Aburto-Oropeza, O., E. Ezcurra, G. Danemann, V. Valdez, J. Murray, and E. Sala. 2008. Mangroves in the Gulf of California increase fishery yields. Proceedings of the National Academy of Sciences of the United States of America 105: 10456-10459.

Adger, W.N. 2006. Vulnerability. Global Environmental Change-Human and Policy Dimensions 16: 268-281.

Adger, W.N., N.W. Arnell, and E.L. Tompkins. 2005a. Successful adaptation to climate change across scales. Global Environmental Change-Human and Policy Dimensions 15: 77-86.

Adger, W.N., T.P. Hughes, C. Folke, S.R. Carpenter, and J. Rockstrom. 2005b. Social-ecological resilience to coastal disasters. Science 309: 1036-1039.

Aguilar Ibarra, A., A. Sanchez Vargas, and B. Martinez Lopez. 2013. Economic impacts of climate change on two Mexican coastal fisheries: Implications for food security. Economics-the Open Access Open-Assessment E-Journal 7: 1-38.

Ahrens, T.D., J.M. Beman, J.A. Harrison, P.K. Jewett, and P.A. Matson. 2008. A synthesis of nitrogen transformations and transfers from 
land to the sea in the Yaqui Valley agricultural region of Northwest Mexico. Water Resources Research 44, W00A05.

Bauer, J.E., W.-J. Cai, P.A. Raymond, T.S. Bianchi, C.S. Hopkinson, and P.A.G. Regnier. 2013. The changing carbon cycle of the coastal ocean. Nature 504: 61-70.

Beman, J.M. 2014. Activity, abundance, and diversity of nitrifying archae and denitrifying bacteria in sediments of a subtropical estuary: Bahia del Tóbari, Mexico. Estuaries and Coasts doi:10.1007/s12237-013-9716-y.

Bezaury-Creel, J.E. 2005. Protected areas and coastal and ocean management in Mexico. Ocean \& Coastal Management 48: 1016-1046.

Bianchi, T.S. 2007. Biogeochemistry of Estuaries. Oxford: Oxford University Press.

Bianchi, T.S., J.R. Pennock, and R.R. Twilley. 1999. Biogechemistry of gulf of Mexico estuaries. John Wiley \& Sons.

Borja, A., and D.M. Dauer. 2008. Assessing the environmental quality status in estuarine and coastal systems: Comparing methodologies and indices. Ecological Indicators 8: 331-337.

Borja, A., S.B. Bricker, D.M. Dauer, N.T. Demetriades, J.G. Ferreira, A.T. Forbes, P. Hutchings, X. Jia, R. Kenchington, J.C. Marques, and C. Zhu. 2008. Overview of integrative tools and methods in assessing ecological integrity in estuarine and coastal systems worldwide. Marine Pollution Bulletin 56: 1519-1537.

Burgos, A.J., M. Maass, G. Ceballos, M. Equihua, E. Jardel, R.A. Medellin, C.A. Hernandez, R. Ayala, and A. Equihua. 2007. La Investigacion Ecologica a Largo Plazo (LTER) y su proyeccion en Mexico. Ciencia y Desarrollo 33: 24-31.

Calderon-Aguilera, L.E., V.H. Rivera-Monroy, L. Porter-Bolland, A. Martinez-Yrizar, L.B. Ladah, M. Martinez-Ramos, J. Alcocer, A.L. Santiago-Perez, H.A. Hernandez-Arana, V.M. Reyes-Gomez, D.R. Perez-Salicrup, V. Diaz-Nunez, J. Sosa-Ramirez, J. HerreraSilveira, and A. Burquez. 2012. An assessment of natural and human disturbance effects on Mexican ecosystems: Current trends and research gaps. Biodiversity and Conservation 21: 589-617.

Camacho-Valdez, V., A. Ruiz-Luna, A. Ghermandi, and P.A.L.D. Nunes. 2013. Valuation of ecosystem services provided by coastal wetlands in northwest Mexico. Ocean \& Coastal Management 78: 1-11.

Carrillo-Rivera, J.J., A. Cardona, R. Huizar-Alvarez, and E. Graniel. 2008. Response of the interaction between groundwater and other components of the environment in Mexico. Environmental Geology 55: 303-319.

Collins, S.L., S.R. Carpenter, S.M. Swinton, D.E. Orenstein, D.L. Childers, T.L. Gragson, N.B. Grimm, M. Grove, S.L. Harlan, J.P. Kaye, A.K. Knapp, G.P. Kofinas, J.J. Magnuson, W.H. McDowell, J.M. Melack, L.A. Ogden, G.P. Robertson, M.D. Smith, and A.C. Whitmer. 2011. An integrated conceptual framework for long-term social-ecological research. Frontiers in Ecology and the Environment 9: 351-357.

Contreras-Espinosa, F., and B.G. Warner. 2004. Ecosystem characteristics and management considerations for coastal wetlands in Mexico. Hydrobiologia 511: 233-245.

Cruz, I., and R.J. McLaughlin. 2008. Contrasting marine policies in the United States, Mexico, Cuba and the European Union: Searching for an integrated strategy for the Gulf of Mexico region. Ocean \& Coastal Management 51: 826-838.

Day, J.W., D.F. Boesch, E.J. Clairain, G.P. Kemp, S.B. Laska, W.J. Mitsch, K. Orth, H. Mashriqui, D.J. Reed, L. Shabman, C.A. Simenstad, B.J. Streever, R.R. Twilley, C.C. Watson, J.T. Wells, and D.F. Whigham. 2007. Restoration of the Mississippi Delta: Lessons from Hurricanes Katrina and Rita. Science 315: 1679-1684.

Delgado-Gonzalez, O.E., J.A. Jimenez, I. Espejel, J.L. Ferman-Almada, A. Martinez-Diaz-de-Leon, A. Mejia-Trejo, and G. Seingier. 2011. Aquaculture potential of Mexican Coasts. Journal of Coastal Research 27: 1137-1147.

Espinoza-Tenorio, A., I. Espejel, and M. Wolff. 2011. Capacity building to achieve sustainable fisheries management in Mexico. Ocean \& Coastal Management 54: 731-741.
Farfán, L.M., E.J. D'Sa, K. Liu, and V.H. Rivera-Monroy. 2014. Tropical cyclone impacts on coastal regions: the case of the Yucatán and the Baja California peninsulas, Mexico. Estuaries and Coasts doi:10. 1007/s12237-014-9797-2.

Gallopin, G.C. 2006. Linkages between vulnerability, resilience, and adaptive capacity. Global Environmental Change-Human and Policy Dimensions 16: 293-303.

Gonzalez-Zamorano, P., S.E. Lluch-Cota, and E.H. Nava-Sanchez. 2013. Relation between the structure of mangrove forests and geomorphic types of lagoons of the Baja California Peninsula. Journal of Coastal Research 29: 173-181.

Hopkinson, C.S., A.E. Lugo, M. Alber, A.P. Covich, and S.J. Van Bloem. 2008. Forecasting effects of sea-level rise and windstorms on coastal and inland ecosystems. Frontiers in Ecology and the Environment 6: 255-263.

Jardel, P., M. Maass, and V.H. Rivera-Monroy. 2013. La Investigación Ecológica de Largo Plazo en México. Mexico: Editorial Universitaria- Universidad de Guadalajara.

Jauregui, E. 2003. Climatology of landfalling hurricanes and tropical storms in Mexico. Atmosfera 1: 193-204.

Lluch-Cota, S.E., E.A. Aragon-Noriega, F. Arreguin-Sanchez, D. Aurioles-Gamboa, J.J. Bautista-Romero, R.C. Brusca, R. Cervantes-Duarte, R. Cortes-Altamirano, P. Del-Monte-Luna, A. Esquivel-Herrera, G. Fernandez, M.E. Hendrickx, S. HernandezVazquez, H. Herrera-Cervantes, M. Kahru, M. Lavin, D. LluchBelda, D.B. Lluch-Cota, J. Lopez-Martinez, S.G. Marinone, M.O. Nevarez-Martinez, S. Ortega-Garcia, E. Palacios-Castro, A. ParesSierra, G. Ponce-Diaz, M. Ramirez-Rodriguez, C.A. Salinas-Zavala, R.A. Schwartzlose, and A.P. Sierra-Beltran. 2007. The Gulf of California: Review of ecosystem status and sustainability challenges. Progress in Oceanography 73: 1-26.

Lozano, L.O., V.S. Weiss, and A.G. Barba. 2000. Scientific research in the Tamaulipas Coastal Zone, Mexico: Implications for its coastal management. Ocean \& Coastal Management 43: 927-936.

Margalef, R., M. Estrada, and D. Blasco. 1979. Functional morphology of organisms involved in red tides, as adapted to decaying turbulence. In Toxic Dinoflagellate Blooms, eds. D. Taylor and H. Seliger, 89 94. New York: Elsevier.

Martínez Arroyo, A., S. Manzanilla Naim, and J. Zavala Hidalgo. 2011. Vulnerability to climate change of marine and coastal fisheries in México. Atmosfera 24: 103-123.

McGranahan, G., D. Balk, and B. Anderson. 2007. The rising tide: Assessing the risks of climate change and human settlements in low elevation coastal zones. Environment and Urbanization 19: $17-37$.

Medina-Gómez, I., B. Kjerfve, I. Mariño, and J. Herrera-Silveira. 2014. Sources of salinity variation in a coastal lagoon in a Karst landscape. Estuaries and Coasts doi:10.1007/s12237-014-9774-9.

Michael, J.K., and H.W. Paerl. 2010. Coastal Lagoons: Critical habitats of environmental change. Boca Raton,: CRS Press.

Murray, G. 2007. Constructing paradise: the impacts of big tourism in the Mexican coastal zone. Coastal Management 35: 339-355.

Nelson, D.R., W.N. Adger, and K. Brown. 2007. Adaptation to environmental change: Contributions of a resilience framework. In Annual Review of Environment and Resources, eds. 395-419.

NWCM-CONAGUA. 2008. Statistics on Water in Mexico 2008 National Water Commission of Mexico.

Ortiz-Lozano, L., A. Granados-Barba, V. Solis-Weiss, and M.A. GarciaSalgado. 2005. Environmental evaluation and development problems of the Mexican Coastal Zone. Ocean \& Coastal Management 48: $161-176$

Paez-Osuna, F., S.R. Guerrero-Galvan, and A.C. Ruiz-Fernandez. 1998. The environmental impact of shrimp aquaculture and the coastal pollution in Mexico. Marine Pollution Bulletin 36: 65-75.

Perry, E., A. Paytan, B. Pedersen, and G. Velazquez-Oliman. 2009. Groundwater geochemistry of the Yucatan Peninsula, Mexico: 
Constraints on stratigraphy and hydrogeology. Journal of Hydrology 367: 27-40.

Rivera-Arriaga, E., and G. Villalobos. 2001. The coast of Mexico: Approaches for its management. Ocean \& Coastal Management 44: 729-756.

Rivera-Arriaga, E., and G.J. Villalobos-Zapata. 2005. The, coastal zone of Campeche, Mexico: Opportunities for implementing an integrated coastal management framework. Journal of Coastal Research 42: 184-190.

Rivera-Monroy, V.H., M. Maass, J.A. Benitez, C. Coronado-Molina, J. Euan, E. Godinez-Dominguez, H. Gonzalez, J. Herrera, L.M. Martínez Rivera, M.M.S. Marlin Perez, V. Reyes, F. Rodriguez, and D. Valdes. 2008. Ecohidrologia y Demanda de Agua en Mexico. Ciencia y Desarrollo 34: 5-29.

Rivera-Monroy, V.H., R.R. Twiley, J.E. Mancera-Pineda, C.J. Madden, A. Alcantara-Eguren, E.B. Moser, B.R. Jonsson, E. CastañedaMoya, O. Casas- Monroy, P. Reyes-Forero, and J. Restrepo. 2011. Saiinty and chlorophyll a as performance measures to rehabilitate a mangrove-dominated deltaic coastal region: the Ciénaga Grande de Santa Marta-Pajarales Lagoon Complex, Colombia. Estuaries and Coasts 34: 1-19.

Ruiz-Luna, A., and C.A. Berlanga-Robles. 2003. Land use, land cover changes and coastal lagoon surface reduction associated with urban growth in northwest Mexico. Landscape Ecology 18: 159-171.

Sanchez-Gil, P., A. Yanez-Arancibia, J. Ramirez-Gordillo, J.W. Day, and P.H. Templet. 2004. Some socio-economic indicators in the Mexican states of the Gulf of Mexico. Ocean \& Coastal Management 47: 581-596.

Seingier, G., I. Espejel, J. Luis Ferman-Almada, O. Delgado Gonzalez, G. Montano-Moctezuma, I. Azuz-Adeath, and G. Aramburo-Vizcarra. 2011. Designing an integrated coastal orientation index: a crosscomparison of Mexican municipalities. Ecological Indicators 11: 633-642.

Sommer, U. 1985. Differential migration of cryptophyceae in Lake Constance. Contributions in Marine Science 27: 166-175.

Stalker, J.C., R.M. Price, V.H. Rivera-Monroy, J. Herrera-Silveira, S. Morales, J.A. Benitez, and D. Alonzo-Parra. 2014. Hydrologic dynamics of a subtropical estuary using geochemical tracers, Celestún, Yucatan, Mexico. Estuaries and Coasts doi:10.1007/ s12237-014-9778-5.
Turner II, B.L. 2010. Vulnerability and resilience: Coalescing or paralleling approaches for sustainability science? Global Environmental ChangeHuman and Policy Dimensions 20: 570-576.

Turner, B.L., R.E. Kasperson, P.A. Matson, J.J. McCarthy, R.W. Corell, L. Christensen, N. Eckley, J.X. Kasperson, A. Luers, M.L. Martello, C. Polsky, A. Pulsipher, and A. Schiller. 2003a. A framework for vulnerability analysis in sustainability science. Proceedings of the National Academy of Sciences of the United States of America 100: 8074-8079.

Turner, B.L., P.A. Matson, J.J. McCarthy, R.W. Corell, L. Christensen, N. Eckley, G.K. Hovelsrud-Broda, J.X. Kasperson, R.E. Kasperson, A. Luers, M.L. Martello, S. Mathiesen, R. Naylor, C. Polsky, A. Pulsipher, A. Schiller, H. Selin, and N. Tyler. 2003b. Illustrating the coupled human-environment system for vulnerability analysis: Three case studies. Proceedings of the National Academy of Sciences of the United States of America 100: 8080-8085.

Varona-Cordero, F., F.J. Gutiérrez-Mendieta, and V.H. Rivera-Monroy. 2014. In situ response of phytoplankton to nutrient additions in a tropical coastal lagoon, (La Mancha, Veracruz, Mexico). Estuaries and Coasts doi:10.1007/s12237-014-9806-5.

Vidal, L., and L.C. Filograsso. 2008. Quantitative analysis of natural resource regulations leading to coastal ecosystems sustainability: Mexico as a case study. Journal of Coastal Research 24: 876889.

Winant, C., A. Valle-Levinson, A. Ponte, C. Winat, G. Gutierrez-de-Velasco, and K. Winters. 2014. Observations on the lateral structure of wind-driven flows in a stratified, semiarid bay of the Gulf of California. Estuaries and Coasts doi:10.1007/s12237-013-9641-0.

Yañez-Arancibia, A., and J.W. Day. 2004a. Environmental sub-regions in the Gulf of Mexico coastal zone: the ecosystem approach as an integrated management tool. Ocean \& Coastal Management 47: 727-757.

Yañez-Arancibia, A., and J.W. Day. 2004b. The Gulf of Mexico: Towards an integration of coastal management with large marine ecosystem management. Ocean \& Coastal Management 47: 537-563.

Yañez-Arancibia, A., J.W. Day, and E. Reyes. 2013. Understanding the coastal ecosystem-based management approach in the gulf of Mexico. Journal of Coastal Research 63: 244-262. 